\title{
Impact of Product Mix and Corporate Governance Practices on Earnings Volatility-Evidence from Banking Sector of Pakistan
}

\author{
Natasha Yaqub ${ }^{1}$ \\ Department of Business Administration, Fatima Jinnah Women University, Pakistan
}

Huma Ayub ${ }^{2 *}$

Department of Business Administration, Fatima Jinnah Women University, Pakistan

\begin{abstract}
The study examines the relationship between product mix and corporate governance on earnings volatility with the help of degree of total leverage (DTL) model. The present study attempts to fill the gap by investigating the relationship between product mix and corporate governance on earnings volatility for developing financial market during the period of 2005-2015. Earnings volatility is analysed by two proxies' i.e. revenue volatility and degree of total leverage. This study has used mainly two types of product mix that consists of lending and fee-based activities while board size, board independence and CEO power is used to measure corporate governance. The results of the study signify the adverse impact of fee-based activities on earnings volatility in the banking sector of Pakistan. Corporate governance confirms the board size and power of CEO in the board as contributing factors to control earnings volatility. The findings are useful to the bankers and regulators to comprehend the role of diversification and corporate governance in creating value and reducing risk for the stakeholders.
\end{abstract}

Keywords: Corporate Governance, Degree of total leverage, Diversification, Earnings Volatility, Product Mix

\section{Introduction}

Banking sector acts as "lifeblood" of an economy and is considered to be the most significant in any country. The earnings of the banks are achieved due to the activities of lending, investment, trading, deposits etc. The core business of any bank is lending. Due to the technological changes, banks are capable of introducing new functions and diversify its products. For that purpose, banks need to introduce that product mix that will result into more profitability and less risks. Bankers tried to increase their earnings

https://doi.org/10.30537/sijmb.v3i2.95

${ }^{1}$ natasha.raja@hotmail.com

2 huma_ayub@fjwu.edu.pk

${ }^{*}$ Corresponding Author

SIJMB | E-ISSN: 2410-1885; P-ISSN: 2313-1217 @ 2016 Sukkur Institute of Business Administration - All rights reserved 
and the increased competition in credit activities between banks exerts banks to shift to new strategies of looking for non-interest income. This shift in product mix activities leads to benefit in developed societies while case is still uncovered for developing countries. The results of different income structures on the risk-return profile of banks are quite unclear (Busch \& Kick, 2015). In developing countries, non-interest income expanded faster than interest income because fee-based activities are least reactive regarding fluctuations in rate of interest and deterioration of the economy. Banks are exploiting the opportunities to diversify in fee-based activities to gain more earnings Nguyen and Vo (2015).

The governance of financial institution has been a hot and debatable topic because of the crisis of 2008 (Vallascas \& Hagendorff, 2013), while the apprehension about the catastrophic role of corporate governance is studied with regards to performance in the banking industry (Kirkpatrick, 2009). As diversification improves bank's performance, therefore corporate governance does the same purpose to improve the overall performance of banking sector. This means that banks' governance performs a paramount responsibility owing to the distinction in the product mix. Good governance leads to an efficient execution of governance while prohibiting the arrogation of directing owners along with the guarantee of prudent decision-making (Ali Shah, Butt, \& Hassan, 2009).

Altering the products of banks can alter the basic mechanism in failure of commercial banks in Pakistan. The main reason behind the failure of banks related to the write offs of loans that are not paid back. Moreover, the decrease in the profits from any of the activities of banks guides the bank to use retained earnings for its capital accumulation. The change of activities from traditional loan to fee-based can also contribute in the failure of banks. The effect of over diversification leads to the failure of banks because it increases the volatility in banking system due to increase in the fixed expenditure DeYoung and Roland (2001).

The Banking sector of Pakistan shows progress in terms of profit after tax in 2015 is PKR 199 billion against the last year profit of PKR 163 billion because of increase in lending and investment in government securities which resulted in the $16.8 \%$ growth in the asset base of the banking industry. The total lending activities of all the banks increased from PKR 919 billion to PKR 981 billion in 2015. The non-mark-up/ feebased income also increases from PKR 167 billion to PKR 108 billion SBP Quarterly Performance Review (2016).

Current study also aims to understand the role of directors (i.e. inside members on board) under Stewardship theory Donaldson and Davis (1994) and focuses on the association among board independence and the performance of the bank under Agency theory Fama and Jensen (1983). For corporate governance, mostly the board members meet 5 to 8 times during a year depending upon the requirement of each bank in

Sukkur IBA Journal of Management and Business | Volume 3 No. 2 July - December 2016 @ Sukkur Institute of Business Administration 
Pakistan. The code recommended that the ideal size of the board ranges from 5-16 members depending upon the size of the organization and the representation of independent directors and the executive directors should not be more than $75 \%$ of the total board size Javed and Iqbal (2007).

The study aims to link the role of corporate governance in product mix and earnings volatility, because from literature it is evident that the board of directors help in improving the performance. The main focus is to investigate whether the effective corporate governance can help banks in their diversification strategy and reduction in risk and insolvency of banks. The study use panel data technique to regress the effect of product mix and corporate governance on earnings volatility. The results show the adverse impact of diversification on earnings volatility. Corporate governance shows the significant impact on earnings volatility.

\subsection{Significance of the Study}

An important significance of the current study is to bring it in closer context of the earning volatility managed with the help of corporate governance and to check whether the diversification make any bank able to reduce the riskiness or insolvency ultimately.

The study provides policy implications for bankers whether to use diversification as a strategy to reduce earnings volatility and insolvency of banks. It provides future implications for policy makers. This study is useful for regulators i.e. State Bank of Pakistan to control the activities of banks and to keep them safe from any uncertain situation like liquidity and insolvency.

The present study adds on the previous literature by incorporating the role of corporate governance in contributing the strategies about product mix and earning volatility in the developing countries like Pakistan. This situation needed to be considered for developing countries. This study focuses on the banking sector of Pakistan to provide the fresh empirical evidence for the developing countries.

\section{Theoretical Foundation}

The theoretical underpinning of the study is based on the literature of product mix, corporate governance, and earning volatility, which helps to understand the background and foundation of the topic.

\subsection{Degree of Total Leverage Model}

A company which has a higher ratio of the fixed-to-variable expenses is considered to have a greater "degree of leverage." This phenomenon has summarized the association among the upper and lower figures in the income statement of a company. When the sales proceeds are excessive in an "extremely levered" firm, then the proportionate increase will be shown by the profits of the company because of the less variable cost

Sukkur IBA Journal of Management and Business | Volume 3 No. 2 July - December 2016 @ Sukkur Institute of Business Administration 
which contributed in relatively large portion of every additional revenue dollar. The degree of leverage of company could be explained more accurately as the proportion change in its profit $(\pi)$ induced by a $1 \%$ change in revenue $(r)$ :

$$
D T L=\frac{\delta \pi}{\delta r} * \frac{r}{\pi}=\frac{\% \Delta \pi}{\% \Delta r}
$$

Conversely, degree of total leverage is the proportionate change in revenue of profits. Degree of total leverage is frequently demonstrated such as outcome of further two leverage convictions, the extent of operating leverage and the measure of financial dominance (namely, Degree of total leverage $=$ Degree of operating leverage $*$ Degree of financial leverage). Degree of operating leverage is the proportionate of profits prior to earnings before interest and taxes regarding proceeds from sales and expresses born for productivity. Degree of financial leverage is the proportionate of earnings concerning earnings before interest and taxes to determine benefit from financial leverage. From these ideas, leverage concerning financial activities is much accustomed in field of banks. In this study, DTL is being emphasized as the diversification in product mix of banks may have an impact equally on operating and financial leverage, owing to the fact that it is difficult to actually distinguish interest expenses of banks into two leverage expenses.

While reorganizing equation (a), it may be stated that increased DTL could magnify specified weight for volatility in revenues into more volume of volatility in profits $(\% \Delta$ $\pi)$ :

$$
\% \Delta \pi=D T L * \% \Delta r
$$

A firm which has many products such as banks; the two changes in revenue and degree of total leverage were affected due to blend in products. Multiple activities of organizations appeared to be several output demand curves, a few of them are much inconsistent than others, and subsequently part of particular product revenue outflows is considered to be slightly high turbulent as compared to others. By considering it as an example, it might be logically anticipated that the surge of returns from amalgamation and procurement is explosive as compared to the profits flows from cover duties imposed on main investors. Thereby, bank's altogether revenue volatility could differ considerably relying on the diversity of products. Likewise, DTL in multiactivities of the company rests on the diversification of products, as every activity is not assembled to costs of fixed and variable ratios.

\subsection{Financial Intermediation Theory}

The theory of financial intermediation is founded by Akerlof (1995), Diamond (1984) and many others. Their perception of financial intermediation was the combination of institutions, tools and markets that satisfy the needs of various economic entities. The

Sukkur IBA Journal of Management and Business | Volume 3 No. 2 July - December 2016 ○ Sukkur Institute of Business Administration 
modification of the traditional financial intermediation theory of banks was fully made by Ukrainian scientists Vishnevsky (2008) who explained the functions of banks quality, quantity and temporal transformation. This modification is the result of financial innovation, universalization, strong competition and diversification in the banking industry Zaernjuk, Kryukova, Bokareva, and Chernikova (2014).

In 70s, the theory of financial intermediation was based on transaction and information approaches. Information approach was founded by the phenomenon of asymmetry of information as explained by the creditor and borrower bank relationship. Information approach was proposed by George A. Akerlof, the leading theorists of information economy. He presented the universality of information asymmetry phenomenon, its presence at many markets Akerlof (1995).

Transaction approach is related to the phenomenon of transaction costs in economy and their impact on organization and conducting of economic and financial activity. Scholes, Benston, and Smith (1976) was the pioneer of presenting the association among financial intermediation and the transaction costs. They explained the main reason of the existence of financial intermediation was market friction and transaction costs because of the imperfection in the markets Scholes et al. (1976).

\subsection{Agency theory}

The Agency theory is studied with line up the matters of the owners and managers (Fama (1980); Fama and Jensen (1983); Stano (1976)) and it depends upon the proposition as there is an innate clash associated with the interests of proprietors of a company and its management Fama and Jensen (1983). The agency dilemma is identified (Eisenhardt (1989); Fama (1980); Fama and Jensen (1983)), which explains that the interest of the management can be observed in benefits like perks (big offices, first class tickets, etc.) that even the profits can be sacrificed in achieving the benefits of perquisites Stano (1976). There must be some monitoring strategy that helped the shareholders to protect them from managers' interest which is also called agency cost and the monitoring mechanism protect the shareholders Fama and Jensen (1983).

The impacts of the agency theory on corporate governance (CG) research examine two key questions. i.e. how a firm's capability can be influenced by the development of the board of directors (Barnhart and Rosenstein (1998); Wagner III, Stimpert, and Fubara (1998)) and also how the leadership structure of organization (i.e., the duality of the $\mathrm{CEO} /$ chairman role) impacts the corporate performance of an organization Dalton, Daily, Ellstrand, and Johnson (1998).

According to the mechanism through which the board is expected to create impact on the corporate performance, the agency theory specifies that a larger proportion of independent directors will be able to monitor self-interests of the managers. Due to this monitoring, managers will not get chance to work for their self-interest that resulted into less agency cost and therefore owners will enjoy higher profits. This model is

Sukkur IBA Journal of Management and Business | Volume 3 No. 2 July - December 2016 @ Sukkur Institute of Business Administration 
extensively accepted in the business world and universally adopted emphasising the need for independent chairpersons to keep an eye on the actions of the board Kiel and Nicholson (2003).

\subsection{Stewardship theory}

Stewardship theory assumes that the managers of an organization are unavoidably reliable human beings and so they are very good guardians of the wealth which endowed to them (Donaldson (1990); Donaldson and Davis (1994)). All of the above, the inside directors pass their working lifestyle in the organization which they regulate; they can comprehend the business more as compared to any outside member of the organization and therefore can formulate better decisions (Donaldson (1990); Donaldson and Davis (1994)). As a result, the supporters of this theory claim that the higher corporate performance will be associated with most of the internal directors as they may normally working for profit of the shareowners. In the accustomed term of motivation MacGregor (1960), the stewardship theory serves as the "Theory Y" facade of managers to agency's "Theory X" view, reasoning that an exaggeration on observing is non-essential for the board of directors to impact on the corporate performance.

Under Stewardship theory managers are usually trustable (Donaldson (1990); Donaldson and Davis (1994)) with a minimum agency costs and the top executives are unlikely to affect share shareholders returns for the fear of compromising on their reputation Donaldson and Davis (1994).

According to the agency theory, there is no evident applied proof to bear anyone claim that a supremacy of the inside directors provides a high combined performance. As this theory is a reflection of the agency theory, it is worth repeating that the overwhelming indication of both from separate works e.g. (Daily and Dalton (1993); Kesner, Victor, and Lamont (1986)) and meta-inspection (Dalton et al. (1998); Rhoades, Rechner, and Sundaramurthy (2000)) ineffective to specify any clear relationship among the board formation and/or leadership construction and the corporate performance.

\section{Theoretical Framework}

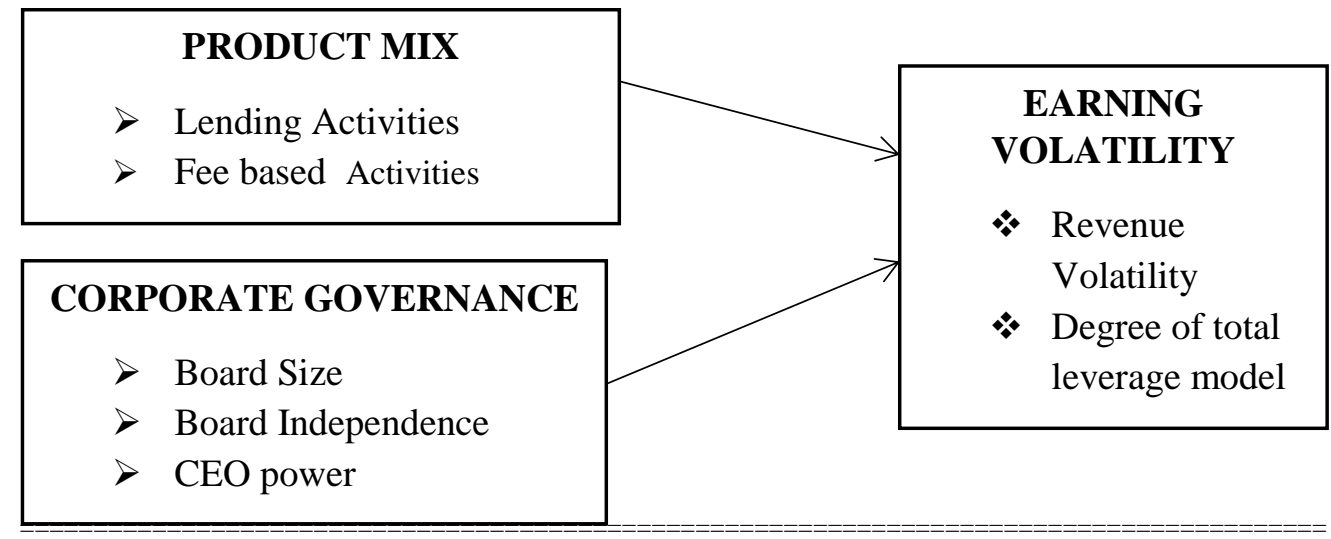

Sukkur IBA Journal of Management and Business | Volume 3 No. 2 July - December 2016 @ Sukkur Institute of Business Administration 
Relationship of each given category of the annual report product mix and corporate governance is studied for their respective impact on the earning volatility. The relationships are studied as to how earning volatility is affected by the corporate governance and product mix with the items of traditional lending activities, fee-based activities, board size, board independence and CEO power on revenue volatility and degree of total leverage.

\section{Methodology}

In this paper, banking sector of Pakistan constituted the proposed population. Currently, there were 33 banks operating in the country. Therefore, population constituted of Public, commercial, and Islamic banks. Due to the variation in the changes in the implementation of policy among the public, private, specialized and foreign banks, the data induced biasness if gathered from all 33 banks because specialized and foreign banks have different policy changes. Hence, population should be adjusted to have only public, private, commercial and Islamic banks. This study considered 26 commercial and Islamic banks in its sample. The sample that was used in this study was the annual basis. The annual reports from 2005-2015 of banks were analyzed and used to test the hypothesis. Considering the sample size of 26 public, commercial and Islamic banks and time period of 11 years, the total observations size becomes 286 .

The given table 4.1 provided the construction of the variables

Table 4.1: Construction of the Variables

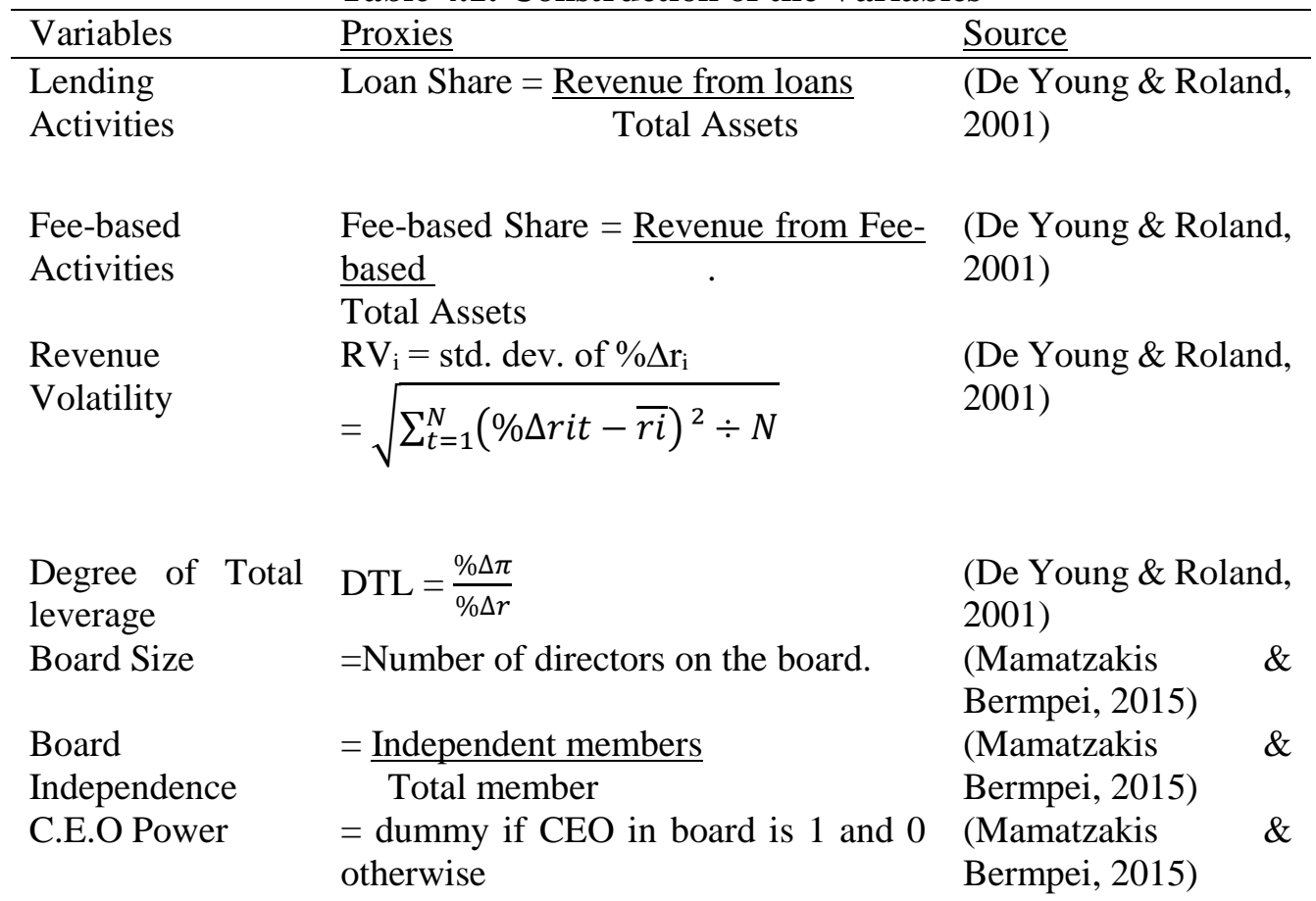

Sukkur IBA Journal of Management and Business | Volume 3 No. 2 July - December 2016 @ Sukkur Institute of Business Administration 
Natasha et al. / Impact of Product Mix and Corporate Governance Practices on Earnings Volatility-Evidence from

\begin{tabular}{|c|c|c|}
\hline Bank Size & $=\ln ($ Total Assets $)$ & $\begin{array}{l}\text { (Brown \& Dinc, } \\
2011)\end{array}$ \\
\hline GDP & $=$ Annual GDP growth & $\begin{array}{l}\text { (Mergaerts \& Vennet, } \\
\text { 2015) }\end{array}$ \\
\hline Interest Rate & $=$ Annual Lending rate & $\begin{array}{l}\text { (Delis \& Kouretas, } \\
\text { 2011) }\end{array}$ \\
\hline
\end{tabular}

\section{Results}

This section includes the analysis of the study and presented the results of the Pakistani banking sector. The data analysis is presented with descriptive statistics, regression results using fixed and random technique. The results are confirmed by checking the robustness of the data of Islamic and Commercial banks. This section presents evidence for the impact of product mix and corporate governance on the earnings volatility of the sample banks in Pakistan.

\subsection{Statistical Data Analysis \\ 5.1.1. Descriptive Statistics}

Table 5.1: Descriptive Statistics

\begin{tabular}{|c|c|c|c|c|c|c|}
\hline Variables & $\underline{\text { Mean }}$ & Max. & Min. & $\underline{\text { Std. Dev. }}$ & $\underline{\text { Skewness }}$ & $\underline{\text { Kurtosis }}$ \\
\hline${ }^{1} \mathrm{RV}$ & 0.096 & 0.372 & 0.0007 & 0.067 & 0.949 & 2.239 \\
\hline${ }^{1} \mathrm{DTL}$ & 0.219 & 1.265 & -1.062 & 0.534 & 0.625 & 1.103 \\
\hline${ }^{2} \mathrm{LA}$ & 0.191 & 0.385 & 0.051 & 0.048 & 0.729 & 2.065 \\
\hline${ }^{2}$ Fee Act. & 0.018 & 0.119 & $8.05 \mathrm{e}-06$ & 0.022 & 0.935 & 1.376 \\
\hline${ }^{3}$ Board size & 8.572 & 14 & 4 & 1.798 & 0.734 & 2.979 \\
\hline${ }^{3}$ Board indp. & 0.410 & 0.875 & 0 & 0.235 & 0.324 & 2.478 \\
\hline${ }^{3} \mathrm{CEO}$ power & 0.963 & 1 & 0 & 0.187 & -0.978 & 2.787 \\
\hline${ }^{2}$ Size & 8.171 & 9.248 & 5.678 & 0.577 & -0.677 & 2.688 \\
\hline${ }^{4} \mathrm{GDP}$ & 3.88 & 7.7 & 1.6 & 1.889 & 0.440 & 2.310 \\
\hline $\begin{array}{l}{ }^{4} \text { Interest } \\
\text { Rate }\end{array}$ & 12.49 & 14.5 & 9.1 & 1.622 & -0.556 & 2.527 \\
\hline
\end{tabular}

Sukkur IBA Journal of Management and Business | Volume 3 No. 2 July - December 2016 @ Sukkur Institute of Business Administration 
Natasha et al. / Impact of Product Mix and Corporate Governance Practices on Earnings Volatility-Evidence from

Note. $\mathrm{N}=26, \mathrm{~T}=11,{ }^{1}$ obs. $=223,{ }^{2}$ obs. $=231,{ }^{3}$ obs. $=222,{ }^{4}$ obs.$=286$

The reported values of mean for revenue volatility (RV) were 0.096 , and the standard deviation was 0.067 for the entire period of ten years. This means that the volatility in revenue of sample banks remained at $9.6 \%$ of the total revenues generated by banks with the variation of $+6.7 \%$. The highest observed value for revenue volatility is 0.372 of the total revenue for JS Bank in 2007. Out of the total product mix, lending activities showed the mean value of 0.191 with the standard deviation of $4.8 \%$.

In corporate governance variables, board size is the most common that depicted the mean of 8.572 for the entire sample with a deviation of 1.798 . Board independence shows the number of independent directors on board that had the mean value of 0.41 with the deviation of $23.5 \%$.

CEO Power depicted the mean value of 0.963 with the standard deviation of $18.7 \%$. As this variable is taken as a proxy so the maximum value is 1 and the minimum value is 0 . All the banks had the value of 1 in all years except JS bank that had the 0 value for the period of 2006 to 2013.

Bank size is micro-control variable while GDP and Interest rates are macro-controlling variables. These control variables are used because they have direct impact on the earnings and volatility of bank. Mean value of GDP is 3.88 with the estimated deviation of 1.889. Whereas, its maximum value is 7.7 in 2005 and the minimum value is 1.6 in 2009 which is a period of world economic recession. Similarly, interest rate has the average value of 12.49 with the deviation of 1.622 .

The Skewness and kurtosis depict the normality of the statistics. For normally distributed figures, the values of Skewness lie between 1 to -1 and the value of kurtosis range between 3 to -3 Bai and $\mathrm{Ng}$ (2005). All the variables under discussion fulfill the requirements and are normally distributed.

\subsubsection{Pearson Correlation Matrix}

The matrix for the impartial variables is shown in Table 5.2. According to Washington et al. (2010) Pearson's correlation matrix demonstrates the correlation of the variables, especially among the independent variables. A Strong correlation (i.e. value of coefficient $>0.80$ ) between the independent variables results into the problem of multicollinearity.

Table 5.2: Pearson Correlation Coefficient Matrix

\begin{tabular}{|c|c|c|c|c|c|}
\hline & $\underline{\mathrm{LA}}$ & Fee Act. & Board Size & Board Ind. & CEO Power \\
\hline${ }^{1} \mathrm{LA}$ & 1 & & & & \\
\hline${ }^{1}$ Fee Act. & $0.207 * * *$ & 1 & & & \\
\hline${ }^{2}$ Board Size & $-0.091 *$ & $\overline{-}-014 * * *$ & 1 & & \\
\hline
\end{tabular}

Sukkur IBA Journal of Management and Business | Volume 3 No. 2 July - December 2016 ○ Sukkur Institute of Business Administration 
Natasha et al. / Impact of Product Mix and Corporate Governance Practices on Earnings Volatility-Evidence from

\begin{tabular}{llllll}
${ }^{2}$ Board Indp. & $-0.186^{* *}$ & $-0.056^{*}$ & 0.041 & 1 & \\
${ }^{2}$ CEO Power & 0.062 & -0.053 & $0.035^{* *}$ & -0.051 & 1 \\
\hline
\end{tabular}

Note. $\mathrm{N}=26, \mathrm{~T}=11,{ }^{1}$ obs. $=231,{ }^{2}$ obs. $=222$

$* \mathrm{p}<.1, * * \mathrm{p}<.05$, and $* * * \mathrm{p}<.01$

The values of correlation coefficients in the table 5.2 suggested that there exist no multicollinearity problem. All the variables have weak correlation. Hence, it ruled out the issue of multicollinearity. These correlation values established grounds for hypothesis testing.

\subsubsection{Variance Inflation Factor}

Table 5.3: Variance Inflation Factor (VIF)

\begin{tabular}{lll}
\hline Variables & $\underline{\text { VIF }}$ & $\underline{1 / \mathrm{VIF}}$ \\
\hline LA & 1.19 & 0.837 \\
Fee Act. & 1.27 & 0.790 \\
Board Size & 1.02 & 0.978 \\
Board Indp. & 1.06 & 0.943 \\
CEO power & 1.05 & 0.952 \\
Size & 1.10 & 0.905 \\
GDP & 4.03 & 0.170 \\
Interest Rates & 4.01 & 0.169 \\
\hline
\end{tabular}

Variance inflation factor $(V I F)$ and tolerance are the tests that are used to detect the multicollinearity in the model of study. This is considered to be the best measure of multicollinearity than Pearson correlation matrix. VIF is the advanced form. The higher the VIF, the more collinear the variables are and vice versa. 1/VIF is called tolerance and $1 /$ tolerance is the VIF (O’Brien, 2007).

The standard value of VIF should be less than five and the value of tolerance must be higher than 0.1 which is shown by $0.05<$ VIF $<5$ (O'Brien, 2007). All the variables fulfill the conditions of VIF and tolerance that shows no multicollinearity. This means that the independent variables are not correlated with each other. 
Natasha et al. / Impact of Product Mix and Corporate Governance Practices on Earnings Volatility-Evidence from

\subsubsection{Test for Model Specification}

Ramsey RESET test is used to check the model specification error. If some relevant variable is not included or some irrelevant variable is included then there appears an error called model specification error Bera and Jarque (1982). The null hypothesis for this test is that model has no omitted variables. In both cases of revenue volatility and degree of total leverage, the null hypothesis accepted and indicated that there are no omitted variables in the regression equation. The result of specification error signifies that null hypothesis is not rejected and there exists no errors in the model.

Table 5.4: Ramsey RESET Test

\begin{tabular}{lll}
\hline & $\underline{\text { RV }}$ & $\underline{\text { DTL }}$ \\
\hline $\mathrm{F}(3,203)$ & 1.68 & 2.31 \\
Prob. & 0.1721 & 0.0779
\end{tabular}

$\mathrm{H}_{0}$ : Model has no omitted variables

\subsubsection{Test for Heteroskedasticity}

Table 5.5: Breusch-Pagan / Cook-Weisberg Test

\begin{tabular}{lll}
\hline & $\underline{\mathrm{RV}}$ & $\underline{\mathrm{DTL}}$ \\
\hline $\mathrm{Chi}^{2}$ & 0.18 & 0.33 \\
Prob. & 0.672 & 0.563 \\
\hline
\end{tabular}

$\mathrm{H}_{0}$ : Constant variance

The main proposition of $O L S$ regression is the homogeneity in the variances of the residuals. In this study, Breusch-Pagan test is used to find the consistency in variances. The null hypothesis shows that the variances are constant Breusch and Pagan (1979). If the value of probability is more and the value of chi-square is less, the alternate hypothesis will be rejected. This indicates that there is no heteroskedasticity and the variances are constant.

\subsubsection{Regression Results}

The regression technique to compute results in this study are fixed and random effects panel least square. This regression technique is used because the data is panel and it has cross sections and time series properties. This analysis technique contains the information necessary to explain intertemporal changes and the individuality of the entities being examined (Fox, 1997). The results of panel data techniques i.e. regression effect model and its related tests are discussed as follows:

Sukkur IBA Journal of Management and Business | Volume 3 No. 2 July - December 2016 @ Sukkur Institute of Business Administration 


\subsubsection{Fixed effect panel least square}

Table 5.6 provides the results of fixed effect panel least square of revenue volatility and degree of total leverage with independent and controlled variables. The value of regression in revenue volatility related to lending activities was $24.5 \%$ which means that 1 unit increase in lending activities reduces revenue volatility by $24.5 \%$. The association turned out to be significant at $10 \%$ that depicted the increase in lending activities decreases revenue volatility. Fee-based activities have a positive significant impact on revenue volatility. The increase in fee-based activities with 1 unit will increase revenue volatility by $45.1 \%$; significant at $1 \%$.

Table 5.6: Fixed Effect Panel Least Square

\begin{tabular}{|c|c|c|c|c|}
\hline & $\underline{\mathrm{RV}}$ & & $\underline{\text { DTL }}$ & \\
\hline Variable & $\frac{\text { Parameter }}{\text { Estimate }}$ & $\underline{\mathrm{t}-\mathrm{stats}}$ & $\frac{\text { Parameter }}{\text { Estimate }}$ & $\underline{\text { t-stats }}$ \\
\hline Constant & 0.834 & $3.25 * * *$ & 4.980 & $2.85 * * *$ \\
\hline LA & -0.245 & $-1.90 *$ & -1.178 & -1.63 \\
\hline Fee Act. & 0.451 & $3.57 * * *$ & 6.101 & $4.26 * * *$ \\
\hline Board Size & 0.005 & 1.10 & 0.036 & 1.07 \\
\hline Board Indp. & 0.003 & 0.08 & 0.232 & 1.62 \\
\hline CEO Power & -0.086 & $-3.90 * * *$ & 0.118 & 0.83 \\
\hline Size & -0.057 & -1.48 & -0.468 & $-2.29 * *$ \\
\hline GDP & -0.005 & -1.43 & -0.054 & -1.11 \\
\hline Interest rate & -0.014 & $-3.07 * * *$ & -0.086 & $-1.80 *$ \\
\hline Ramsey RESET & & 0.1721 & & 0.0779 \\
\hline $\mathrm{R}^{2}$ & & 0.3430 & & 0.2173 \\
\hline $\mathrm{F}$ & & $11.88 * * *$ & & $5.70 * * *$ \\
\hline
\end{tabular}

Note. $\mathrm{N}=26, \mathrm{~T}=11$, obs. $=215$

$* \mathrm{p}<.1, * * \mathrm{p}<.05$, and $* * * \mathrm{p}<.01$

Board size, board independence, size, and GDP are insignificant under fixed effect model. CEO power and interest rates showed negative significant impacts that reflect that they are contributing in the reduction in revenue volatility. CEO power and interest rates are significant at $1 \% . \mathrm{R}^{2}$ indicated that $34.30 \%$ of the variations in the dependent 
variable are contributed by the independent variables. F-statistics indicate the significance of the model at $1 \%$.

The above table also provides the output of the regression using fixed effect model related to degree of total leverage. Fee-based activities have positive significant impact at $1 \%$ level of significance. Corporate governance variables and lending activities show insignificant impact on degree of total leverage. Size of the bank Afzal and Mirza (2012) and interest rate have negative impact significant at 5\% and 10\% respectively. The $\mathrm{R}^{2}$ is $21.73 \%$ of the variations in DTL. However, the model is significant at $1 \%$.

\subsubsection{Random effect panel least square}

Table 5.7 exhibits the results of OLS estimates applying random effect model for both dependent variables. The value of regression coefficients shows inverse significant relationship in lending activities, CEO power Donaldson and Davis (1994) interest rate and size of bank with revenue volatility DeYoung and Rice (2004), significant at $1 \%$. GDP is negatively significant at $10 \%$.

Table 5.7: Random Effect Panel Least Squares

\begin{tabular}{|c|c|c|c|c|}
\hline & $\underline{\mathrm{RV}}$ & & $\underline{\text { DTL }}$ & \\
\hline Variable & $\frac{\text { Parameter }}{\text { Estimate }}$ & $\underline{z \text {-stats }}$ & $\begin{array}{l}\text { Parameter } \\
\text { Estimate }\end{array}$ & $\underline{z \text {-stats }}$ \\
\hline Constant & 0.715 & $5.03 * * *$ & 2.724 & $3.19 * * *$ \\
\hline Lending Activities & -0.286 & $-2.90 * * *$ & -2.023 & $-2.40 * *$ \\
\hline Fee-based Activities & 0.569 & $4.32 * * *$ & 5.629 & $3.38 * * *$ \\
\hline Board Size & 0.007 & $1.80 *$ & 0.037 & $1.97 * *$ \\
\hline Board Independence & -0.004 & -0.16 & 0.228 & $1.87 *$ \\
\hline CEO power & -0.104 & $-9.88 * * *$ & -0.086 & $-2.03 * *$ \\
\hline Size & -0.033 & $-2.31 * *$ & -0.015 & -0.39 \\
\hline GDP & -0.008 & $-1.71 *$ & -0.096 & $-1.69 *$ \\
\hline Interest Rate & -0.018 & $-3.72 * * *$ & -0.161 & $-3.03 * * *$ \\
\hline Ramsey RESET & & 0.1721 & & 0.0779 \\
\hline $\mathrm{R}^{2}$ & & 0.3327 & & 0.1898 \\
\hline $\mathrm{Chi}^{2}$ & & $856.43 * * *$ & & $199.07 * * *$ \\
\hline
\end{tabular}

Note. $\mathrm{N}=26, \mathrm{~T}=11$, obs. $=215$

$* \mathrm{p}<.1, * * \mathrm{p}<.05$, and $* * * \mathrm{p}<.01$

Sukkur IBA Journal of Management and Business | Volume 3 No. 2 July - December 2016 @ Sukkur Institute of Business Administration 
Fee-based activities depict positive impact significant at 1\%. 1 unit change in fee-based activities brings $56.9 \%$ increase in the revenue volatility. Board size is positively significant with revenue volatility at $1 \%$ level of significance (Lipton \& Lorsch, 1992). Board independence shows insignificant relationship with the dependent variable. The model explained for $33.27 \%$ of the variations in dependent variable. The value of $\mathrm{chi}^{2}$ shows the significance of model at $1 \%$.

The table also shows the results of random effect panel least square of the degree of total leverage. Landing activities depict strong negative association Amidu and Wolfe (2013) with DTL i.e. 1 unit increase in lending activities results into the $240 \%$ decrease in the degree of total leverage; $5 \%$ significance. Fee-based activities have positive relationship with DTL significant at $1 \%$. Board size depicts positive association with degree of total leverage at 5\% significance Pathan and Faff (2013). Board independence is positively significant at $1 \%$. It means that the increase in board independence results in the increase in earnings volatility of banks. CEO power is negatively significant at $5 \%$ which shows that the presence of CEO in the board of directors results into the reduction in earnings volatility of banks in Pakistan. GDP and interest rate shows negative association with degree of total leverage significant at $10 \%$ and $1 \%$ respectively. Size of banks shows insignificant relationship. The $\mathrm{R}^{2}$ is $15.86 \%$ of the variations in dependent variable.

The regression analysis could incorporate either one of the effects either fixed or random based on the results of Haussmann tests.

\subsubsection{Haussmann specification test:}

Haussmann test was applied to get the most significant model and consistent effects for assessment. Haussmann test signifies whether random effect is suitable for study or fixed effect is appropriate for that specific research. The results of the Haussmann test are given in table 5.8. There is an assumption for random effects that is; no covariance among the independent variables and the error terms. This is null hypothesis in Haussmann specification test. If probability values are less than 0.05 than alternate hypothesis is accepted and the null hypothesis is rejected. Therefore, fixed effect model will be used. On the other hand, if the values of probability are greater than 0.05 then random effect model will be applied to explain the results of the aforesaid study Hausman (1978).

Table 5.8: Haussmann Specification Test

\begin{tabular}{|c|c|c|c|c|c|c|}
\hline & & $\underline{\mathrm{RV}}$ & & & DTL & \\
\hline Variable & Fixed & Random & $\delta^{2}$ (Diff.) & Fixed & Random & $\delta^{2}$ (Diff.) \\
\hline LA & -0.246 & -0.287 & 0.041 & -1.179 & -2.023 & 0.845 \\
\hline Fee Act. & 0.451 & 0.569 & -0.118 & 6.101 & 5.629 & 0.471 \\
\hline
\end{tabular}

Sukkur IBA Journal of Management and Business | Volume 3 No. 2 July - December 2016 @ Sukkur Institute of Business Administration 
Natasha et al. / Impact of Product Mix and Corporate Governance Practices on Earnings Volatility-Evidence from

\begin{tabular}{lcccccc}
\hline Board Size & 0.006 & 0.007 & -0.001 & 0.037 & 0.037 & -0.000 \\
Board Indp. & 0.003 & -0.005 & 0.007 & 0.232 & 0.228 & 0.004 \\
CEO Power & -0.086 & -0.104 & 0.018 & 0.118 & -0.086 & 0.205 \\
Size & -0.057 & -0.033 & -0.024 & -0.469 & -0.015 & -0.454 \\
GDP & -0.005 & -0.008 & 0.003 & -0.054 & -0.096 & 0.042 \\
Interest Rate & -0.014 & -0.018 & 0.004 & -0.086 & -0.161 & 0.075 \\
Ramsey & & & 0.1721 & & & 0.0779 \\
RESET & & & & & & \\
Chi-Sq. & & & 5.10 & & & 0.2270 \\
Prob. & & & 0.7463 & & &
\end{tabular}

Note. $\mathrm{N}=26, \mathrm{~T}=11$, obs. $=215$

The table 5.8 shows that the null hypothesis of Haussmann specification test is accepted in revenue volatility and degree of total leverage, so random effect is used to apply the most accurate results for the hypotheses of revenue volatility and degree of total leverage in this study. In the Haussmann test, there appears a very small difference which shows no covariance among variables.

\subsection{Robustness Checks}

Robustness checks are used to clarify the hypothesis as suggested by DeYoung and Roland (2001). The results of random effects are used to explain revenue volatility and degree of total leverage mentioned in this study. To check the robustness, pooled data is applied separately to the data of Islamic banks and robustness to the data of Commercial banks was used and the tests were applied. These tests proved the results of random effect model for revenue volatility and results of fixed effect model for degree of total leverage.

Table 5.9: Robustness Checks of Islamic Banks vs. Commercial Banks in Pakistan

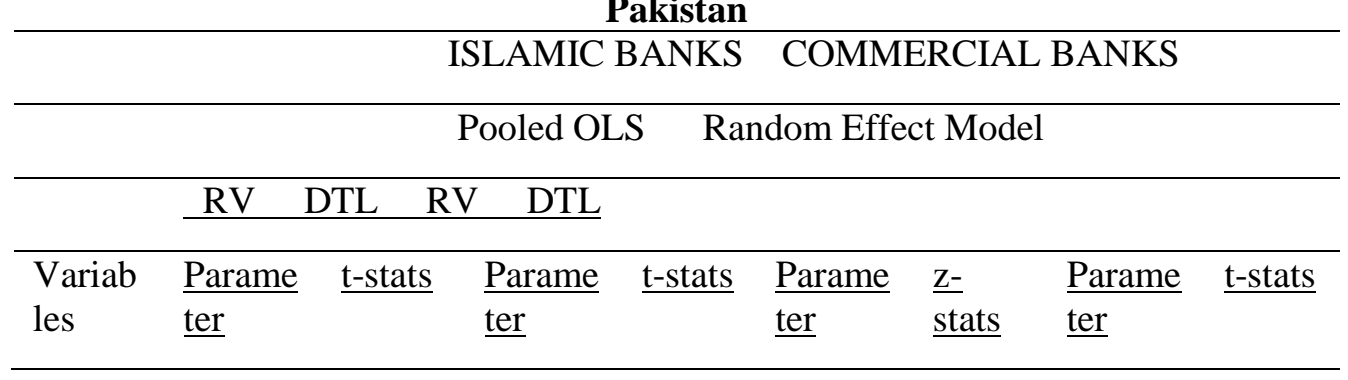

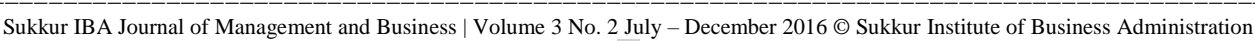


Natasha et al. / Impact of Product Mix and Corporate Governance Practices on Earnings Volatility-Evidence from

\begin{tabular}{|c|c|c|c|c|c|c|c|c|}
\hline & $\underline{\mathrm{E}} \underline{\mathrm{estimat}}$ & & $\underline{\mathrm{E}}$ & & $\underline{\mathrm{e}} \underline{\mathrm{estimat}}$ & & $\underline{\text { Estimat }}$ & \\
\hline $\begin{array}{l}\text { Consta } \\
\mathrm{nt}\end{array}$ & 0.737 & $\begin{array}{l}3.93 * * \\
*\end{array}$ & 0.409 & 0.52 & 0.686 & $\begin{array}{l}4.73 * \\
* *\end{array}$ & 2.298 & $\begin{array}{l}3.02 * \\
* *\end{array}$ \\
\hline LA & -0.126 & $\begin{array}{l}- \\
4.30 * * \\
*\end{array}$ & -0.288 & $\begin{array}{l}- \\
2.29 * \\
*\end{array}$ & -0.372 & $\begin{array}{l}- \\
5.38 * \\
* *\end{array}$ & -2.513 & $\begin{array}{l}- \\
2.97 * \\
* *\end{array}$ \\
\hline $\begin{array}{l}\text { Fee } \\
\text { Act. }\end{array}$ & 0.480 & $1.69 *$ & 8.652 & $\begin{array}{l}10.81 \\
* *\end{array}$ & 0.449 & $\begin{array}{l}2.54 * \\
*\end{array}$ & 3.778 & $1.94 *$ \\
\hline $\begin{array}{l}\text { Board } \\
\text { Size }\end{array}$ & 0.013 & $2.25 * *$ & 0.041 & $1.70^{*}$ & 0.003 & 0.82 & 0.035 & $\begin{array}{l}2.62 * \\
* *\end{array}$ \\
\hline $\begin{array}{l}\text { Board } \\
\text { Indp. }\end{array}$ & 0.094 & 1.49 & 0.359 & $\begin{array}{l}4.02 * \\
* *\end{array}$ & -0.029 & -1.13 & 0.003 & 0.02 \\
\hline $\begin{array}{l}\text { CEO } \\
\text { Power }\end{array}$ & & $\begin{array}{l}\text { Omitt } \\
\text { ed }\end{array}$ & $\begin{array}{l}\text { Variabl } \\
\text { e }\end{array}$ & & -0.114 & $\begin{array}{l}- \\
9.18 * \\
* *\end{array}$ & -0.174 & $\begin{array}{l}- \\
4.17 * \\
* *\end{array}$ \\
\hline Size & -0.077 & $\begin{array}{l}- \\
3.30 * * \\
*\end{array}$ & -0.153 & $\begin{array}{l}- \\
1.98^{*} \\
*\end{array}$ & -0.019 & -1.26 & 0.087 & 1.62 \\
\hline GDP & -0.008 & $\overline{-} .54 * *$ & 0.059 & 0.52 & -0.007 & $\begin{array}{l}- \\
2.17 * \\
*\end{array}$ & -0.078 & -1.47 \\
\hline $\begin{array}{l}\text { Interes } \\
\mathrm{t}\end{array}$ & -0.014 & $\overline{-} 1.97 * *$ & 0.006 & 0.13 & -0.019 & $\begin{array}{l}- \\
5.47 * \\
* *\end{array}$ & -0.174 & $\begin{array}{l}- \\
3.18^{*} \\
* *\end{array}$ \\
\hline $\mathrm{R}^{2}$ & & 0.4917 & & $\begin{array}{l}0.523 \\
5\end{array}$ & & $\begin{array}{l}0.411 \\
0\end{array}$ & & $\begin{array}{l}0.188 \\
2\end{array}$ \\
\hline
\end{tabular}

Note. $\mathrm{N}=5, \mathrm{~T}=11$, obs. $=30(I B)$

$\mathrm{N}=21, \mathrm{~T}=11, \mathrm{obs} .=185(C B)$

$* \mathrm{p}<.1, * * \mathrm{p}<.05$, and $* * * \mathrm{p}<.01$

The separate robust results for Islamic and Commercial banks are used to check the validity of the data. Table 5.9 signify the robust results of Islamic and Commercial banks. In case of Islamic banks, the number of cross sections is less than the time period. This contradicts the assumptions of robustness. That's why pooled $O L S$ is used to get the most accurate results. The results of Islamic banks show that lending activities have 
negative significant impact with revenue volatility at $1 \%$ level of significance. Feebased activities have positive impact significant at $10 \%$. Board size has positive significant impact at 5\% Jensen \& Meckling, (1976). Board independence reflects insignificant relationship. CEO power was omitted in case of Islamic banks because all the Islamic banks use CEO duality concept to increase the performance and decrease the volatility in earnings. It is automatically removed by STATA to remove collinearity.

In case of control variables, size, GDP and interest rates have negative significant impact on revenue volatility significant at $1 \%$ and $5 \%$ respectively Chiorazzo, Milani, and Salvini (2008). The $\mathrm{R}^{2}$ is $49.17 \%$ and adjusted $\mathrm{R}^{2}$ is $92.67 \%$ which shows the overall variation in dependent variable due to independent variables.

Table 5.9 indicate the robust results of degree of total leverage by considering Islamic banks data. Lending activities indicate negative effect on degree of total leverage Klein and Saidenberg (1998) while fee-based activities show positive significant impact. Lending activities and fee-based activities were significant at 5\%. The corporate governance variables .i.e. Board size and board independence shows positive significant effect on degree of total leverage with significance at 10\% and 1\%. GDP and interest rates have insignificant impact on degree of total leverage. The $\mathrm{R}^{2}$ is $52.35 \%$.

The robust results of commercial banks for revenue volatility indicate negative relationship with lending activities with $1 \%$ significance and positive relationship with fee-based activities at 5\% level of significance (DeYoung and Roland (2001); Stiroh and Rumble (2006)). CEO power shows strong negative association with revenue volatility Pathan (2009), significant at 1\%. GDP and interest rates have negative relationship with revenue volatility at $5 \%$ and $1 \%$ level of significance. Board size, board independence and size of bank depicts insignificant relationship. The $\mathrm{R}^{2}$ is $41.10 \%$ and the adjusted $\mathrm{R}^{2}$ is $52.12 \%$. As far as DTL is concerned for commercial banks, it shows negative relationship with lending activities, CEO power and interest rate significant at $1 \%$. Fee-based activities and board size shows positive significant relationship with degree of total leverage in commercial Pakistani banks at $10 \%$ and $1 \%$ level of significance. The value of $\mathrm{R}^{2}$ is $18.82 \%$. The robust results proved the regression results for this study.

\section{Discussion}

Lending activities indicated negative significant impact on revenue volatility and degree of total leverage in the Pakistani banks. As the main source of earnings in Pakistani banks is through the loans, so lending activities are more stable and depict that the risk of banks will decrease by increasing lending activities. The degree of total leverage that is the degree of operating leverage and the degree of financial leverage depicted the operating and financing conditions in the banks. The traditional lending activities of the banks are based upon the bank-customer relationship. Because of switching and information costs, it proved to be very difficult for borrowers as well as lenders to stay away from lending activities. As the lending relationship is established

Sukkur IBA Journal of Management and Business | Volume 3 No. 2 July - December 2016 ๑ Sukkur Institute of Business Administration 
so fixed cost is the one time cost for banks and then there exists only the variable costs that make operating costs less for the banks. Moreover, financial leverage can be reduced by banks because they have to hold some equity capital against outstanding loan balances DeYoung and Roland (2001). The decrease in operating and financial leverage result into decrease in total leverage and the risk of bank is reduced. Similarly, (Amidu and Wolfe (2013); Chiorazzo et al. (2008); Gurbuz, Yanik, and Ayturk (2013); Stiroh and Rumble (2006)) validated that the lending activities are more stable and reduced earnings volatility.

Fee- based activities showed positive significant relationship with revenue volatility and degree of total leverage in the banking industry of Pakistan. While non-interest income is regarded an essential source of diversification but in contrast with the conventional view; DeYoung and Roland (2001) identified that non-interest income increases the earnings volatility of banks and the same is true for Pakistani banks. Stiroh and Rumble (2006) signify that product diversification is the important element in an increase in bank risks. Low switching cost; high operating and financial leverage essentials for fee based activities formulate non-interest earnings more volatile related to traditional interest based activities. Over-diversification of revenues raises the risk of insolvency rather than raising profits Delpachitra and Lester (2013). Moreover, the strategies relating to diversification need great care because extensive diversification can decrease the financial performance of banking industry (Sahoo \& Mishra, 2012). Stiroh and Rumble (2006) explained non- interest earning is more volatile than interest earning but may not be more beneficial.

The hypothesis regarding the impact of board size on revenue volatility and degree of total leverage states that board members have significant impact on revenue volatility and degree of total leverage. The findings relating to this hypothesis shows that board size has a positive impact on revenue volatility and degree of total leverage in Pakistan. This result is similar to agency cost hypothesis mainly for the banks that have more than ten members on board. The board members may have different views that will result into the conflict. That conflict is agency conflict. The inevitable part of agency costs is the relationship between managers and owner. This suggests that an increase in the number of board members could result in information asymmetry and communication costs Jensen and Meckling (1976). Similarly Lipton and Lorsch (1992) and Pathan and Faff (2013) also support the similar results.

The other variable that is board independence is being rejected by this study. It shows insignificant impact of board independence in banking industry of Pakistan with revenue volatility. This shows that there is no effect in constitution of board whether it contains outside members or the inside members in the boards of banks in Pakistan. Choi and Hasan (2005) observed the insignificant impact of board independence during their study for the sample of Korean banks from 1998 to 2000.

Board independence shows positive significant impact on degree of total leverage. The inside directors have more knowledge and experience about the banks so the outside

Sukkur IBA Journal of Management and Business | Volume 3 No. 2 July - December 2016 @ Sukkur Institute of Business Administration 
directors may reduce performance and increase volatility in the banking sector of Pakistan Wiseman and Gomez-Mejia (1998). This is in line with the Stewardship hypothesis. The other reason is that the outside members may involve in political activity that could lead in the increase in volatility of the banks' earnings and could reduce the cooperation among inside and outside members Westphal (1999).

CEO power is negatively related to revenue volatility and degree of total leverage in the banking industry of Pakistan in line with the stewardship hypothesis. Donaldson (1990) suggested that the CEO duality enhances the performance because he has strong control over the management of the company. Pathan (2009) found the inverse connection among CEO power with risk taking. It means that CEO duality reduces the risk taking and decreases the volatility in the banks' earnings. Donaldson and Davis (1994) suggested that the inside directors spend more time in the company so they have more knowledge about the company and therefore can take prudent decisions.

Size of banks indicated negative significant impact on revenue volatility in the banks of Pakistan. Bank size has a direct relationship with the performance; it means big banks have better performance as they have more diversification opportunities. Well managed banks gradually move towards diversification and they have larger diversification opportunities as compared to smaller banks (Chiorazzo et al. (2008); DeYoung and Rice (2004)). (Chiorazzo et al. (2008)) revealed that the merits of diversity in product mix are more at the big banks whereas small banks acquire incentives only if the ratios of interest free earnings to whole earnings are comparatively less. The findings confirmed the 'Too big to fail hypothesis' view which states that the big banks have more cushion to absorb risk. They can take more risk with highly profitable opportunities to diversify in product mix activities. Salas and Saurina (2002) indicated that larger banks are less susceptible to risks because they have expert managers who can work efficiently. They also reported that big banks can diversify loan portfolio better due to huge economies of scale and scope. The large banks are able to serve more clients and provide better services to their clients DeYoung and Rice (2004).

Bank Size shows insignificant relationship with degree of total leverage. It means that the operating activities of banks are not affected by the size of the banks in Pakistan because the operating activities depend more on the managerial capacity and efficiency De Jonghe (2010).

GDP and interest rate have negative significant impact on both revenue volatility and degree of total leverage. It shows that the GDP growth of country reduces risks in Pakistani banks. The operating and financial risks are reduced. As the GDP growth reflects prosperity in the country, so it helps in the growth and prosperity of banks accordingly. Most of the banking literature indicates that a high GDP growth signifies the more stable macroeconomic conditions in the country and a relatively less bank stress (Borio and Lowe (2002); Festić, Kavkler, and Repina (2011); Poghosyan and Čihak (2011)). As the interest rates are high, banks engaged in more lending activities and wanted to maximize profits. This results in the increase in probability of earnings

Sukkur IBA Journal of Management and Business | Volume 3 No. 2 July - December 2016 @ Sukkur Institute of Business Administration 
by the customers. As analysed by Black and Scholes (1973) higher levered institutions like banks mostly have greater variation in volatility that increases value of the firm as it enhances the chance of a favourable pay-out to owners. Hoggarth, Sorensen, and Zicchino (2005) found that interest rates and inflation have the negative effect on financial stability and quality of loan portfolio.

\section{Conclusion}

The study concluded that the lending activities have inverse relationship with the revenue volatility and the degree of total leverage in banking sector of Pakistan which has implications for policy makers De Jonghe (2010). Further, fee-based activities demonstrated the adverse impacts with revenue volatility and degree of total leverage which has implications for the risk taking behaviour of banks in Pakistan Mercieca, Schaeck, and Wolfe (2007). Based on the findings of the study conventional school for the diversification is negated and suggested to focus on their lending portfolio to gain maximum advantage out of it with fewer fluctuations in volatility Ismail, Hanif, Choudhary, and Nisar (2015). Board size prescribed to be small because the large board size increased earnings volatility in Pakistani banks. It advocates that the board size has to be small to increase banks performance and decrease volatility Lipton and Lorsch (1992). Board independence depicted positive relationship with DTL which means that the board should not include more independent directors. CEO confirmed the stewardship hypothesis which endorsed the CEO duality in banking sector Pathan (2009). Size of the banks reflected significant relationship with revenue volatility. This is compatible with the concept that growth in bank size decrease volatility of banks earnings and therefore contributes positively in the performance of banks Boyd and Prescott (1986). GDP signified the growth in the country help to reduce volatility in Pakistani banks. This relationship was seen before in the studies of Baselga-Pascual, Trujillo-Ponce, and Cardone-Riportella (2015). Interest rate suggested being high because the increase in interest rate decreases the volatility of earnings.

\subsection{Recommendations}

The findings of present study confirmed the significance of product mix and corporate governance on earnings volatility in the banking industry of Pakistan. The study has useful implications for bankers, regulators (SBP) and policy makers. The following recommendations are based on the findings of this study.

$>$ The study confirmed the usage of lending portfolio as a means for the diversification of risk. Therefore, it is suggested that banks focus on their lending portfolio in the future and build long term relationship with the customers to lessen the switching costs as evident from the work of Stiroh and Rumble (2006).

$>$ From this study, it can also be recommended that banks need to keep the size of the board less than 10. Therefore, the study recommends Al Baraka, Askari and MCB to keep 10 members in board. The large board increases the volatility of banks earnings and therefore decreases the performance. Hence small board size increases efficiency of board members.

Sukkur IBA Journal of Management and Business | Volume 3 No. 2 July - December 2016 @ Sukkur Institute of Business Administration 
$>$ The banks should continue to include CEO as a member of board to increase board efficiency as evident from the literature which is in line with the stewardship theory where CEO duality proved to be more effective.

\subsection{Future Research Avenues}

The following research areas can be sought for further discussion on this topic suggested by the results of this study.

$>$ Further study can be conducted by elaborating each aspect of non-interest portfolio. The separate effect of each income can give more precise results.

$>$ The data set for long periods can be used to find the objectives of research.

$>$ More variables can be included in the corporate governance factor.

$>$ Cross-cultural comparison can be studied further with data of banks from world over.

$>$ The function of fee-related activities in capital needs can be worked out.

\section{References}

Afzal, A., \& Mirza, N. (2012). Size, diversification and risk: preliminary evidence from commercial banks in Pakistan. Pakistan Journal of Commerce and Social Sciences, 6(2), 282-296.

Akerlof, G. (1995). The market for "lemons": Quality uncertainty and the market mechanism Essential readings in economics (pp. 175-188): Springer.

Ali Shah, S. Z., Butt, S. A., \& Hassan, A. (2009). Corporate governance and earnings management an empirical evidence form Pakistani listed companies.

Amidu, M., \& Wolfe, S. (2013). Does bank competition and diversification lead to greater stability? Evidence from emerging markets. Review of Development Finance, 3(3), 152-166.

Bai, J., \& Ng, S. (2005). Tests for skewness, kurtosis, and normality for time series data. Journal of Business \& Economic Statistics, 23(1), 49-60.

Barnhart, S. W., \& Rosenstein, S. (1998). Board composition, managerial ownership, and firm performance: An empirical analysis. Financial Review, 33(4), 1-16.

Baselga-Pascual, L., Trujillo-Ponce, A., \& Cardone-Riportella, C. (2015). Factors influencing bank risk in Europe: Evidence from the financial crisis. The North American Journal of Economics and Finance, 34, 138-166.

Bera, A. K., \& Jarque, C. M. (1982). Model specification tests: A simultaneous approach. Journal of econometrics, 20(1), 59-82.

Black, F., \& Scholes, M. (1973). The pricing of options and corporate liabilities. Journal of political economy, 81(3), 637-654.

Borio, C. E., \& Lowe, P. W. (2002). Asset prices, financial and monetary stability: exploring the nexus.

Boyd, J. H., \& Prescott, E. C. (1986). Financial intermediary-coalitions. Journal of Economic Theory, 38(2), 211-232.

Sukkur IBA Journal of Management and Business | Volume 3 No. 2 July - December 2016 ○ Sukkur Institute of Business Administration 
Breusch, T. S., \& Pagan, A. R. (1979). A simple test for heteroscedasticity and random coefficient variation. Econometrica: Journal of the Econometric Society, 12871294.

Chiorazzo, V., Milani, C., \& Salvini, F. (2008). Income diversification and bank performance: Evidence from Italian banks. Journal of Financial Services Research, 33(3), 181-203.

Choi, S., \& Hasan, I. (2005). Ownership, governance, and bank performance: Korean experience. Financial Markets, Institutions \& Instruments, 14(4), 215-242.

Daily, C. M., \& Dalton, D. R. (1993). Board of directors leadership and structure: Control and performance implications. Entrepreneurship: Theory and Practice, 17(3), 65-82.

Dalton, D. R., Daily, C. M., Ellstrand, A. E., \& Johnson, J. L. (1998). Meta-analytic reviews of board composition, leadership structure, and financial performance. Strategic management journal, 19(3), 269-290.

De Jonghe, O. (2010). Back to the basics in banking? A micro-analysis of banking system stability. Journal of Financial Intermediation, 19(3), 387-417.

Delpachitra, S., \& Lester, L. (2013). Non-Interest Income: Are Australian Banks Moving Away from their Traditional Businesses? Economic Papers: A journal of applied economics and policy, 32(2), 190-199.

DeYoung, R., \& Rice, T. (2004). Noninterest income and financial performance at US commercial banks. Financial Review, 39(1), 101-127.

DeYoung, R., \& Roland, K. P. (2001). Product mix and earnings volatility at commercial banks: Evidence from a degree of total leverage model. Journal of Financial Intermediation, 10(1), 54-84.

Diamond, D. W. (1984). Financial intermediation and delegated monitoring. The Review of Economic Studies, 51(3), 393-414.

Donaldson, L. (1990). The ethereal hand: Organizational economics and management theory. Academy of management review, 15(3), 369-381.

Donaldson, L., \& Davis, J. H. (1994). Boards and company performance-research challenges the conventional wisdom. Corporate governance: An international review, 2(3), 151-160.

Eisenhardt, K. M. (1989). Agency theory: An assessment and review. Academy of management review, 14(1), 57-74.

Fama, E. F. (1980). Agency Problems and the Theory of the Firm. Journal of political economy, 88(2), 288-307.

Fama, E. F., \& Jensen, M. C. (1983). Separation of ownership and control. The journal of law and Economics, 26(2), 301-325.

Festić, M., Kavkler, A., \& Repina, S. (2011). The macroeconomic sources of systemic risk in the banking sectors of five new EU member states. Journal of Banking \& Finance, 35(2), 310-322.

Gurbuz, A. O., Yanik, S., \& Ayturk, Y. (2013). Income diversification and bank performance: Evidence from Turkish banking sector. BDDK Bankacilik ve Finansal Piyasalar, 7(1), 9-29.

Sukkur IBA Journal of Management and Business | Volume 3 No. 2 July - December 2016 @ Sukkur Institute of Business Administration 
Natasha et al. / Impact of Product Mix and Corporate Governance Practices on Earnings Volatility-Evidence from

Hausman, J. A. (1978). Specification tests in econometrics. Econometrica: Journal of the Econometric Society, 1251-1271.

Hoggarth, G., Sorensen, S., \& Zicchino, L. (2005). Stress tests of UK banks using a VAR approach.

Ismail, A., Hanif, R., Choudhary, S., \& Nisar, A. (2015). Income-Diversification In Banking Sector Of Pakistan: A'blessing'Or'curse'? The Journal of Commerce, $7(1), 11$

Javed, A. Y., \& Iqbal, R. (2007). Relationship between corporate governance indicators and firm value: A case study of Karachi stock exchange.

Jensen, M. C., \& Meckling, W. H. (1976). Theory of the firm: Managerial behavior, agency costs and ownership structure. Journal of financial economics, 3(4), 305-360.

Kesner, I. F., Victor, B., \& Lamont, B. T. (1986). Research notes: board composition and the commission of illegal acts: an investigation of fortune 500 companies. Academy of Management Journal, 29(4), 789-799.

Kiel, G. C., \& Nicholson, G. J. (2003). Board composition and corporate performance: How the Australian experience informs contrasting theories of corporate governance. Corporate governance: An international review, 11(3), 189-205.

Klein, P. G., \& Saidenberg, M. R. (1998). Diversification, organization, and efficiency: Evidence from bank holding companies.

Lipton, M., \& Lorsch, J. W. (1992). A modest proposal for improved corporate governance. The business lawyer, 59-77.

MacGregor, D. (1960). The human side of enterprise (Vol. 21): New York.

Mercieca, S., Schaeck, K., \& Wolfe, S. (2007). Small European banks: Benefits from diversification? Journal of Banking \& Finance, 31(7), 1975-1998.

Nguyen, T. C., \& Vo, D. V. (2015). Risk and Income Diversification in the Vietnamese Banking System. Journal of Applied Finance and banking, 5(1), 93.

Pathan, S. (2009). Strong boards, CEO power and bank risk-taking. Journal of Banking \& Finance, 33(7), 1340-1350.

Pathan, S., \& Faff, R. (2013). Does board structure in banks really affect their performance? Journal of Banking \& Finance, 37(5), 1573-1589.

Poghosyan, T., \& Čihak, M. (2011). Determinants of bank distress in Europe: Evidence from a new data set. Journal of Financial Services Research, 40(3), 163-184.

Rhoades, D. L., Rechner, P. L., \& Sundaramurthy, C. (2000). Board composition and financial performance: A meta-analysis of the influence of outside directors. Journal of Managerial issues, 76-91.

Salas, V., \& Saurina, J. (2002). Credit risk in two institutional regimes: Spanish commercial and savings banks. Journal of Financial Services Research, 22(3), 203-224.

Scholes, M., Benston, G. J., \& Smith, C. W. (1976). A transactions cost approach to the theory of financial intermediation. The Journal of Finance, 31(2), 215-231.

Stano, M. (1976). Monopoly power, ownership control, and corporate performance. The Bell Journal of Economics, 672-679. 
Stiroh, K. J., \& Rumble, A. (2006). The dark side of diversification: The case of US financial holding companies. Journal of Banking \& Finance, 30(8), 2131-2161.

Vallascas, F., \& Hagendorff, J. (2013). CEO bonus compensation and bank default risk: evidence from the US and Europe. Financial Markets, Institutions \& Instruments, 22(2), 47-89.

Vishnevsky, V., Matyushin, A \& Annenkov, I. (2008). Modern approaches to the theory of Bank Intermediation. Scientific works of DonSTU, 2(34), 12-22.

Wagner III, J. A., Stimpert, J., \& Fubara, E. I. (1998). Board composition and organizational performance: Two studies of insider/outsider effects. Journal of Management Studies, 35(5), 655-677.

Westphal, J. D. (1999). Collaboration in the boardroom: Behavioral and performance consequences of CEO-board social ties. Academy of Management Journal, 42(1), 7-24.

Wiseman, R. M., \& Gomez-Mejia, L. R. (1998). A behavioral agency model of managerial risk taking. Academy of management review, 23(1), 133-153.

Zaernjuk, V., Kryukova, E., Bokareva, E., \& Chernikova, L. (2014). A study of the theoretical approaches to the banking financial intermediation and its development trends. World Applied Sciences Journal, 30(12), 1723-1725. 